Impact of the fermentation process with immobilized yeast cells on the aroma profile and sensory quality of distillates produced from two fig (Ficus carica L.) cultivars

Utjecaj fermentacije $\mathrm{s}$ imobiliziranim stanicama kvasca na profil arome i senzorsku kvalitetu rakija proizvedenih iz dviju sorti smokve (Ficus carica L.)

Miličević, B., Ačkar, Đ., Babić, J., Jozinović, A., Miličević, R., Oroz, M., Šubarić, D.

Poljoprivreda/Agriculture

ISSN: $1848-8080$ (Online)

ISSN: 1330-7142 (Print)

http://dx.doi.org/10.18047/poljo.23.1.8

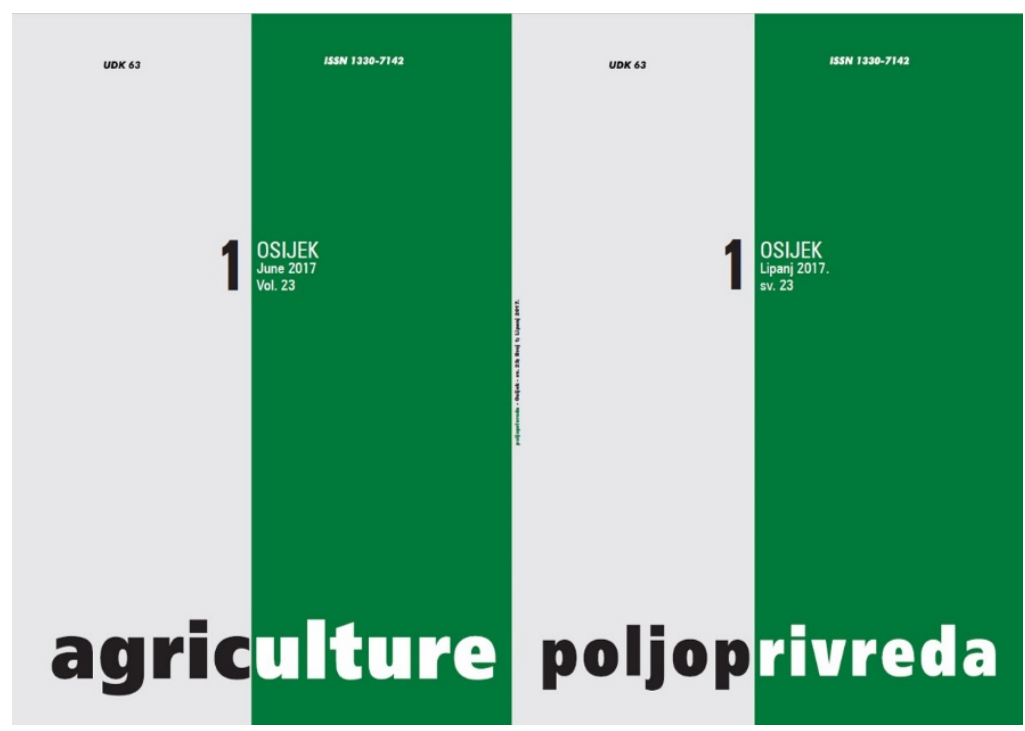

Poljoprivredni fakultet u Osijeku, Poljoprivredni institut Osijek

Faculty of Agriculture in Osijek, Agricultural Institute Osijek 


\title{
IMPACT OF THE FERMENTATION PROCESS WITH IMMOBILIZED YEAST CELLS ON THE AROMA PROFILE AND SENSORY QUALITY OF DISTILLATES PRODUCED FROM TWO FIG (Ficus carica L.) CULTIVARS
}

Miličević, B. ${ }^{(1)}$, Ačkar, $\Theta^{(1)}$, Babić, J. ${ }^{(1)}$, Jozinović, A. ${ }^{(1)}$, Miličević, R. ${ }^{(2)}$, Oroz, M. ${ }^{(3)}$, Šubarić, D. $^{(1)}$

Original scientific paper

Izvorni znanstveni članak

\begin{abstract}
SUMMARY
The aim of this research was to investigate the influence of immobilized cell fermentation on aroma and sensory characteristics of distillates produced from two fig varieties commonly grown in Croatia (Petrovača bijela and Petrovača crna). Distillate samples were produced both by classical and immobilized yeast fermentation technology. Aroma profile was determined using GC/FID and sensory analysis was conducted according to German DLG model. Results showed that immobilized cell technique gives distillates with higher ethanol and lower ester contents, but of higher sensory quality. It is a promising technique for production of high quality fruit distillates.
\end{abstract}

Key-words: immobilized yeast cells, fig, distillate, aroma, sensory quality

\section{INTRODUCTION}

The production of unique fig (Ficus carica L.) distillates has a long tradition in Croatia. Favourable climatic and microclimatic conditions in Croatian region Dalmatia, as well as pedological properties of Croatian soil, in addition to original production factors (alcoholic fermentation, distillation, distillate aging), and choice of the appropriate cultivar result in unique quality of fig (Ficus carica L.) distillates.

Alcoholic beverages produced from this fruit contain many volatile aroma compounds and a number of these compounds, including benzaldehyde, linalool hexanal, phenylacetaldehyde and eugenol, contribute to the typical fruity flavour and aroma (Willemsens and Boelsens, 1996.).

Although quality of alcoholic beverages is influenced by many factors, from raw material quality and production process to storage conditions (Vila et al., 1998; Williams and Piggot, 1983; Singelton, 1995; Soufleros et al., 2005; Lukić et al., 2011), the volatile composition is the main important factor. The composition of volatile aroma compounds in distilled spirits has been widely investigated using gas chromatography and mass spectrometry (Plutowska et al., 2009, 2010; Apostolopoulou et al., 2005; Diéguez et al., 2005; Guan and Pieper, 1998).

The typical flavour of fig (Ficus carica L.) distillates results from both the raw material compounds and compounds developed during technological operation of processing figs into alcoholic beverages (secondary aroma substances), Rotim, 2008.

Many authors have investigated how the secondary aroma substances generated during the fermentation process influenced aroma and total quality of alcoholic beverages, as well as the fermentation process with immobilized yeasts. Lilly et al. (2000) put the main accent to the esters formed during alcoholic fermentation and made an attempt to increase their production

(1) Prof. Dr. Borislav Miličević, Assoc. Prof. Đurđica Ačkar (dackar@ptfos. hr), Prof. Dr. Jurislav Babić, Assist. Prof. Antun Jozinović, Prof. Dr. Drago Subarić - Josip Juraj Strossmayer University of Osijek, Faculty of Food Technology Osijek, F. Kuhača 20, HR-31000 Osijek, Croatia (2) Radoslav Miličević, PhD, Progresys d.o.o., Ind. Park bb, 35400 Nova Gradiška, Croatia, (3) Mirjana Oroz, Zvečevo d.d., Food Industry, Kralja Zvonimira 1 , 34000 Požega, Croatia 
by genetic modification of $S$. cerevisiae. They concluded that increased content of esters may improve the flavour of wines and distillates deficient in aroma. Fundira et al. (2002) investigated the influence of different yeast strains on aroma profile of wines and distillates, and Yayima and Yokotsuka (2001) reported that yeast immobilization resulted in reduced formation of undesirable volatile compounds in wine.

Immobilized yeast technology has attracted continual attention in the industry over the last years (Gaserod, 1998; Vikarjavi and Kronolof, 1998;), because this fermentation procedure provides faster fermentation rates and increased volumetric productivity, giving the possibility of developing continuous operation. Kourkoutas et al. (2004) state that immobilized yeast cell technology has following advantages over free cell technology: prolonged activity and stability of cells, higher cell densities, high volumetric productivity, increased substrate uptake, easier product recovery, reduced risk of microbial contamination, reduced maturation time in some processes etc. The process has been successfully applied in beer, mead, cider, fruit wine and wine production (Nedović et al., 2015). Latest developments in alcoholic beverages production with immobilized yeast cells clearly indicate that by using different reactor and systems design (Poncelet et al., 2001; Miličević et al., 2012) the quality can be increased. All these solutions are promising but there are still numerous factors that must be studied, including aroma composition and physico-chemical properties of specific fermented beverages.

The aim of this research was to determine the impact of the fermentation process with immobilized yeast cells on the physico-chemical characteristics of distillates produced from different varieties of fig (Ficus carica L.).

\section{MATERIAL AND METHODS}

\section{Pulp}

Samples of fig (Ficus carica L.) pulp (harvest 2014) were taken from the technological process of distillate production at "Zvečevo" d.d. Distillate samples were produced from two fig varieties traditionally grown in Croatia: Petrovača bijela and Petrovača crna (List of Varieties of the Republic of Croatia, 2015, Croatian Centre for Agriculture, Food and Rural Affairs). Both varieties give two harvests a year. Petrovača bijela has round fruit with light-green, thin skin and red, juicy, sweet pulp. The first harvest is at the end of June and the second from mid-August to mid-0ctober. Petrovača crna has pear-shaped purple fruit with first fruits from mid-June to mid-July and the second in August. For the research, the first harvest was used in full technologically ripe state.

\section{Pulp fermentation}

Two fermentation procedures were used, each in three replicates. In the first one, samples of Petrovača bijela and Petrovača crna were fermented using the classical technological procedure: fermentation with free yeast/selected yeast Fermol-Bouqet 125 and controlled thermal regime using outer refrigeration of fermenters with running water, with the aim of keeping the average temperature between $18-20^{\circ} \mathrm{C}$. The average duration of fermentation under these conditions was 21 days.

In the second procedure, samples of Petrovača bijela and Petrovača crna were fermented using a technological procedure as shown in Fig. 1: fermentation with yeast cells/selected yeast Fermol-Bouqet 125 immobilized in Ca-alginate gel (Gaserod, 1998; Poncelet et al., 2001), in internal loop gas-lift fermenter (Figure 1) with alginate beads as yeast carriers and controlled thermal regime, using outer refrigeration of fermenters with running water to keep the average temperature between $18-20^{\circ} \mathrm{C}$. The average duration of fermentation under these conditions was $72 \mathrm{~h}$ for each set. The reusability of immobilized cultures was not tested.

In both fermentation procedures, both yeast and commercial yeast nutrient formulation Enovit ${ }^{\circledR}$ were added in amount of $15 \mathrm{~g}$ per $100 \mathrm{~kg}$ of fermentation pulp.

All samples were taken at the end of fermentation before sedimentation, therefore the samples were insufficiently clear and slightly dull, which is appropriate for the selected procedure for the distillate production.

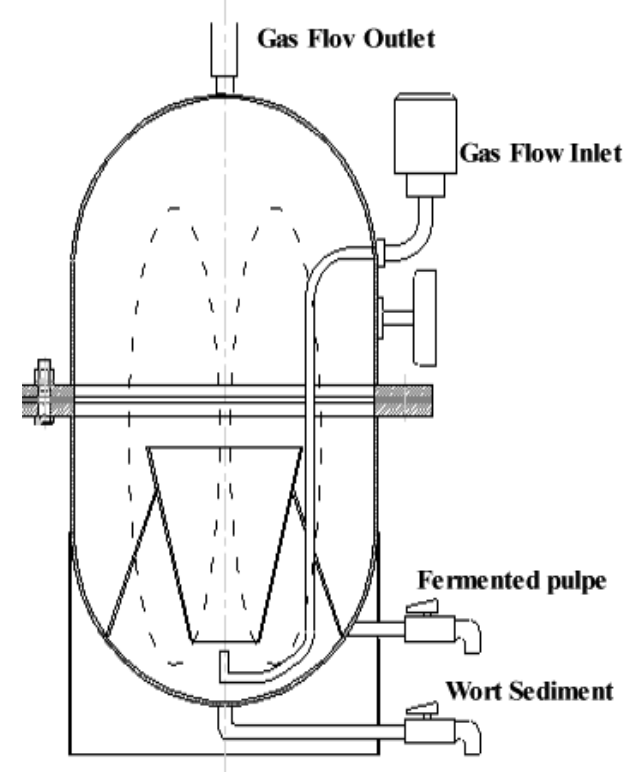

Fig. 1. Reactor for fermentation with immobilized yeast cells. Samples with immobilized cells are put in the fermenter and mixing of the whole batch is done by gas (movement of the material is shown by hyphens) Slika 1. Reaktor za fermentaciju s imobiliziranim stanicama kvasca. Uzorak za fermentaciju s imobiliziranim stanicama kvasca stavlja se u fermentor, a miješanje se vrši pomoću plina (kretanje mase označeno je crticama)

\section{Distillation}

Selected samples were distilled in a copper clip distillation device, according to the procedure indicated in Fig. 2. 


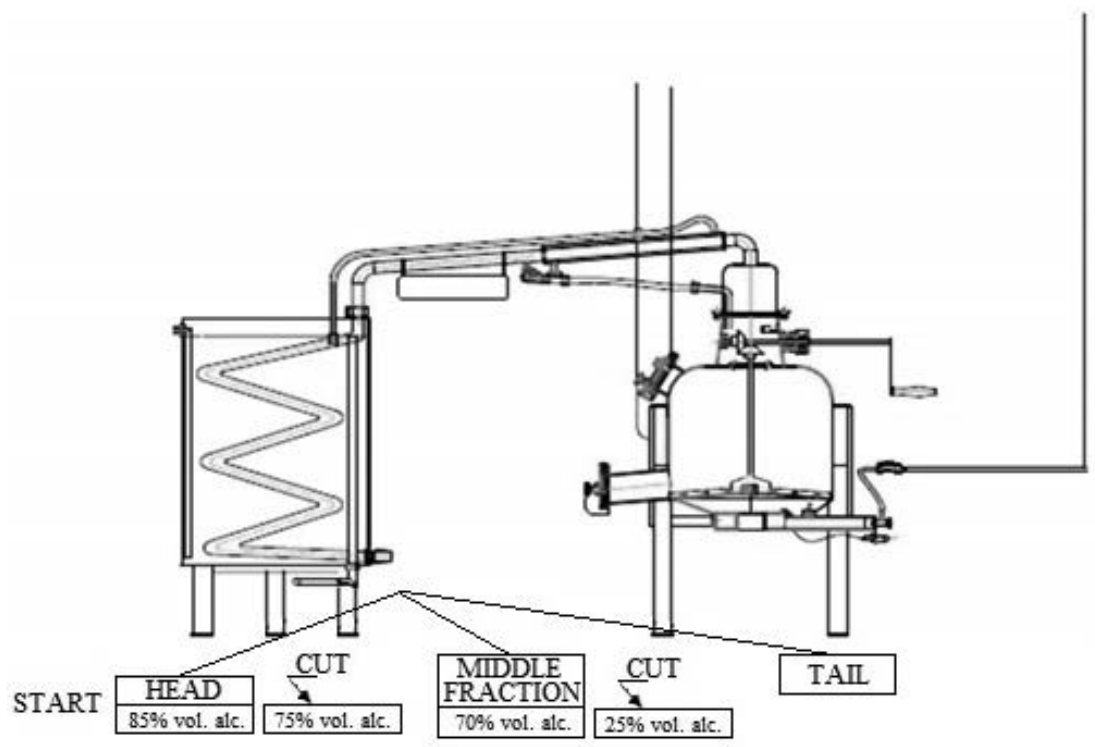

Fig. 2. Procedure of distillation

Slika 2. Proces destilacije

The samples containing approximately $70 \%$ vol. alcohol were taken from the middle fraction, while the first (head) and the last (tail) fraction were not used for volatile compounds determination.

All selected samples were distilled according to the same distillation protocol (Fig. 2).

\section{Analysis of distillates}

Instrumental analytical techniques were applied on the basis of the European Community Reference Methods for the analysis of spirits using gas chromatography (EEC, 2000; EEC, 2008).

Analysis of volatile aroma compounds was done on a Hewlett Packard 5890 gas chromatograph with a split/ splitless injector and FID detector, in triplicate. For the headspace analysis Hewlett Packard sampler HP 7694 was used. Compounds of interest were resolved on a Stabilwax (Restec, USA) capillary column $(30 \mathrm{~m} \times 0.25$ $\mu \mathrm{m}$ i.d. $\times 0.25 \mu \mathrm{m}$ ) with the following parameters: initial oven temperature of $30^{\circ} \mathrm{C}$ was kept for $4 \mathrm{~min}$, then raised by $10^{\circ} \mathrm{C} / \mathrm{min}$ to $100^{\circ} \mathrm{C}$ followed by $25^{\circ} \mathrm{C} / \mathrm{min}$ to $250^{\circ} \mathrm{C}$, and kept at $250^{\circ} \mathrm{C}$ for $7 \mathrm{~min}$. Injection port temperature was kept at $180^{\circ} \mathrm{C}$, pressure was $20 \mathrm{psi}$, and carrier gas (nitrogen) flow was $3 \mathrm{~mL} / \mathrm{min}$. Detector temperature was $250^{\circ} \mathrm{C}$.

The headspace sampler was equipped with a standard $1 \mathrm{~mL}$ loop. Carrier gas pressure was $17 \mathrm{psi}$, vial pressure was $7 \mathrm{psi}$, and injection time was 0.20 min. Samples were heated at $100^{\circ} \mathrm{C}$ for $10 \mathrm{~min}$. For the analysis of distillates, a Stabilwax (Restec, USA) capillary column ( $30 \mathrm{~m} \times 0.25 \mu \mathrm{m}$ i.d. $\times 0.25 \mu \mathrm{m})$ was used, the initial oven temperature was kept at $35^{\circ} \mathrm{C}$ for $7 \mathrm{~min}$, then raised by $10^{\circ} \mathrm{C} / \mathrm{min}$ to $80^{\circ} \mathrm{C}$ followed by $25^{\circ} \mathrm{C} / \mathrm{min}$ to $200^{\circ} \mathrm{C}$, and kept at $200^{\circ} \mathrm{C}$ for $4 \mathrm{~min}$. Quantitative data was obtained using n-amyl alcohol as an internal standard. Qualitative analysis was carried out by combined GC-mass spectrometry (GC/MS) with Stabilwax (Restec, USA) capillary column as well as the comparison of mass spectra and retention index (RI) with reference substances (analytical grade from Merck, Germany) and library data.

Experimental data were analysed by analysis of variance (ANOVA) and Fisher's least significant difference (LSD) with significance defined at $\mathrm{P}<0.05$. All statistical analyses were carried out using software program STATISTICA 12 (StatSoft, Inc, USA). Sensory analysis was performed by ten (10) trained professional sensory judges according to German DLG model - colour, clearness, taste and odour were evaluated with total maximum score of 100 (Koch, 1986).

\section{RESULTS AND DISCUSSION}

The results of chemical analyses of fig distillate samples (Table 1) showed that fermentation with immobilized yeasts results in higher content of ethanol. For Petrovača bijela cultivar, this increase was from $68.01 \%$ vol. to $69.84 \%$ vol., and for Petrovača crna from $68.99 \%$ vol. to $69.90 \%$ vol. As observed before for tangerine distillates (Miličević et al., 2012), immobilization also resulted in approximately the same ethanol content in the distillates obtained from both fig varieties (Table 1), unlike classical fermentation where ethanol content varied with fig cultivar (Table 1).

Methanol content significantly decreased with application of immobilized cell technology, which is a significant result from the safety aspect of alcoholic beverages (Pohanka, 2016). On the other hand, total $\mathrm{SO}_{2}$ concentration increased significantly (from $5.54 \mathrm{mg} / \mathrm{L}$ to $6.04 \mathrm{mg} / \mathrm{L}$ for Petrovača bijela distillate and from 5.85 $\mathrm{mg} / \mathrm{L}$ to $9.20 \mathrm{mg} / \mathrm{L}$ for Petrovača crna distillate). This indicates that the concentration of $\mathrm{SO}_{2}$ added to pulp to control undesired fermentation and oxidation process could be reduced, since free $\mathrm{SO}_{2}$ can bind to acetaldehyde, producing a stuffy odour (Guan and Pieper, 1998). 
Table 1. Selected chemical characteristics of fig distillate samples (mean \pm standard deviations)

Tablica 1. Odabrana kemijska svojstva uzoraka destilata smokve

\begin{tabular}{|c|c|c|c|c|}
\hline \multirow[b]{2}{*}{$\begin{array}{l}\text { Assessment characteristics } \\
\text { Parametar }\end{array}$} & \multicolumn{2}{|c|}{$\begin{array}{l}\text { Pulps fermented using classical technological procedure } \\
\text { Klasična fermentacija }\end{array}$} & \multicolumn{2}{|c|}{$\begin{array}{l}\text { Pulps fermented with immobilized yeast cells } \\
\text { Fermentacija s imobiliziranim stanicama kvasca }\end{array}$} \\
\hline & $\begin{array}{l}\text { Petrovača } \\
\text { bijela }\end{array}$ & $\begin{array}{l}\text { Petrovača } \\
\text { crna }\end{array}$ & $\begin{array}{l}\text { Petrovača } \\
\text { bijela }\end{array}$ & $\begin{array}{l}\text { Petrovača } \\
\text { crna }\end{array}$ \\
\hline Total extract $(\mathrm{g} / \mathrm{L})$ & $0.064 \pm 0.01^{c}$ & $0.034 \pm 0.02^{b}$ & $0.018 \pm 0.02^{\mathrm{a}}$ & $0.011 \pm 0.03^{\mathrm{a}}$ \\
\hline Total SO $\mathrm{S}_{2}(\mathrm{mg} / \mathrm{L})$ & $5.54 \pm 0.02^{\mathrm{a}}$ & $5.85 \pm 0.01^{b}$ & $6.04 \pm 0.03^{c}$ & $9.20 \pm 0.02^{d}$ \\
\hline Total acidity (mg/L) & $457.60 \pm 0.03^{c}$ & $485.00 \pm 0.02^{d}$ & $247.00 \pm 0.02^{\mathrm{a}}$ & $351.20 \pm 0.02^{b}$ \\
\hline Furfural (mg/L a.a.) & $0.06 \pm 0.02^{\mathrm{a}}$ & $0.04 \pm 0.02^{\mathrm{a}}$ & tr. & tr. \\
\hline Benzaldehyde (mg/L) & $2.29 \pm 0.03^{c}$ & $1.67 \pm 0.02^{b}$ & $1.59 \pm 0.02^{\mathrm{a}, \mathrm{b}}$ & $1.49 \pm 0.06^{\mathrm{a}}$ \\
\hline $\begin{array}{l}\text { 2-Furancarboxaldehyde, } \\
5 \text { (hydroxymethyl) }\end{array}$ & $4.13 \pm 0.01^{\mathrm{a}}$ & $4.19 \pm 0.01^{\mathrm{a}}$ & $5.96 \pm 0.03^{c}$ & $4.57 \pm 0.01^{b}$ \\
\hline Ethanol (\% vol.) & $68.01 \pm 0.02^{\mathrm{a}}$ & $68.99 \pm 0.03^{b}$ & $69.84 \pm 0.02^{c}$ & $69.90 \pm 0.01^{\mathrm{c}}$ \\
\hline Methanol (mg/L a.a.) & $0.12 \pm 0.02^{b}$ & $0.14 \pm 0.02^{b}$ & $0.08 \pm 0.02^{\mathrm{a}}$ & tr. \\
\hline 1-propanol (mg/L) & $2.75 \pm 0.01^{b}$ & $4.70 \pm 0.03^{d}$ & $1.00 \pm 0.01^{\mathrm{a}}$ & $3.70 \pm 0.02^{c}$ \\
\hline 1-butanol (mg/L) & $0.15 \pm 0.01^{a, b}$ & $0.20 \pm 0.02^{b}$ & $0.09 \pm 0.01^{\mathrm{a}}$ & $0.10 \pm 0.03^{\mathrm{a}}$ \\
\hline Isobutyl alcohol (mg/L) & $3.62 \pm 0.01^{\mathrm{b}}$ & $3.90 \pm 0.03^{c}$ & $3.42 \pm 0.02^{\mathrm{a}}$ & $3.60 \pm 0.032^{b}$ \\
\hline Isoamyl alcohol (mg/L) & $8.79 \pm 0.01^{c}$ & $9.90 \pm 0.01^{\mathrm{d}}$ & $5.39 \pm 0.03^{\mathrm{a}}$ & $6.39 \pm 0.03^{b}$ \\
\hline 2-phenyl ethanol (mg/L) & $2.97 \pm 0.01^{b}$ & $4.52 \pm 0.01^{\mathrm{d}}$ & $2.75 \pm 0.01^{\mathrm{a}}$ & $3.45 \pm 0.01^{c}$ \\
\hline Linalool (mg/L) & $0.92 \pm 0.02^{b}$ & $0.62 \pm 0.03^{\mathrm{a}}$ & $0.98 \pm 0.03^{b}$ & $0.65 \pm 0.03^{\mathrm{a}}$ \\
\hline$\alpha$-Terpineol (mg/L) & $2.17 \pm 0.02^{b}$ & $1.57 \pm 0.01^{\mathrm{a}}$ & $2.84 \pm 0.01^{\mathrm{d}}$ & $2.44 \pm 0.01^{c}$ \\
\hline Nerolidol (mg/L) & $0.06 \pm 0.02^{\mathrm{a}}$ & tr. & $0.08 \pm 0.02^{\mathrm{a}}$ & $0.07 \pm 0.02^{\mathrm{a}}$ \\
\hline Limonene (mg/L) & $0.11 \pm 0.03^{\mathrm{a}}$ & tr. & $0.19 \pm 0.02^{b}$ & $0.19 \pm 0.01^{b}$ \\
\hline$\beta$-Caryophyllene (mg/L) & $4.45 \pm 0.02^{b}$ & $4.33 \pm 0.01^{\mathrm{a}}$ & $5.38 \pm 0.01^{d}$ & $5.15 \pm 0.02^{c}$ \\
\hline$\alpha$-humulene (mg/L) & $2.09 \pm 0.01^{b}$ & $1.27 \pm 0.01^{\mathrm{a}}$ & n.d. & n.d. \\
\hline Germacrene D (mg/L) & $4.96 \pm 0.01^{\mathrm{a}}$ & $5.06 \pm 0.01^{b}$ & $5.10 \pm 0.01^{c}$ & $5.13 \pm 0.01^{c}$ \\
\hline Ethyl lactate $(\mathrm{mg} / \mathrm{L})$ & $0.07 \pm 0.02^{\mathrm{a}}$ & $0.41 \pm 0.02^{b}$ & n.d. & n.d. \\
\hline Ethyl octanoate $(\mathrm{mg} / \mathrm{L})$ & $5.92 \pm 0.01^{d}$ & $2.69 \pm 0.01^{b}$ & $4.18 \pm 0.01^{c}$ & $2.62 \pm 0.01^{\mathrm{a}}$ \\
\hline Ethyl decanoate $(\mathrm{mg} / \mathrm{L})$ & $1.74 \pm 0.02^{b}$ & $0.91 \pm 0.02^{\mathrm{a}}$ & n.d. & n.d. \\
\hline Ethyl acetate $(\mathrm{mg} / \mathrm{L})$ & $6.57 \pm 0.01^{\mathrm{c}}$ & $6.20 \pm 0.01^{b}$ & $4.49 \pm 0.02^{\mathrm{a}}$ & $4.52 \pm 0.01^{\mathrm{a}}$ \\
\hline Isoamyl acetate $(\mathrm{mg} / \mathrm{L})$ & $9.60 \pm 0.01^{d}$ & $9.40 \pm 0.02^{c}$ & $9.02 \pm 0.02^{b}$ & $8.35 \pm 0.01^{\mathrm{a}}$ \\
\hline Acetaldehyde(mg/L) & $5.11 \pm 0.02^{\mathrm{d}}$ & $4.76 \pm 0.03^{c}$ & $4.58 \pm 0.01^{b}$ & $3.15 \pm 0.02^{\mathrm{a}}$ \\
\hline Ethyl hexanoate $(\mathrm{mg} / \mathrm{L})$ & $2.96 \pm 0.02^{\mathrm{d}}$ & $2.11 \pm 0.02^{b}$ & $2.66 \pm 0.02^{c}$ & $2.01 \pm 0.02^{\mathrm{a}}$ \\
\hline Methyl octanoate (mg/L) & $0.56 \pm 0.03^{b}$ & $0.36 \pm 0.02^{\mathrm{a}}$ & $0.46 \pm 0.03^{b}$ & $0.33 \pm 0.03^{\mathrm{a}}$ \\
\hline 2-Phenylethyl acetate $(\mathrm{mg} / \mathrm{L})$ & $0.81 \pm 0.03^{b}$ & $0.61 \pm 0.02^{\mathrm{a}}$ & $0.60 \pm 0.01^{\mathrm{a}}$ & tr. \\
\hline Methyl decanoate (mg/L) & $0.34 \pm 0.01^{b}$ & $0.30 \pm 0.02^{b}$ & $0.25 \pm 0.02^{\mathrm{a}}$ & $0.22 \pm 0.01^{\mathrm{a}}$ \\
\hline Benzyl acetate $(\mathrm{mg} / \mathrm{L})$ & tr. & tr. & tr. & n.d. \\
\hline Ethyl benzoate (mg/L) & tr. & tr. & tr. & n.d. \\
\hline Ethyl decanoate $(\mathrm{mg} / \mathrm{L})$ & $28.44 \pm 0.01^{\mathrm{a}}$ & $28.44 \pm 0.01^{\mathrm{a}}$ & $28.44 \pm 0.01^{\mathrm{a}}$ & $28.44 \pm 0.01^{\mathrm{a}}$ \\
\hline Isoamyloctanoate $(\mathrm{mg} / \mathrm{L})$ & $0.41 \pm 0.02^{b}$ & $0.36 \pm 0.02^{\mathrm{a}, \mathrm{b}}$ & $0.40 \pm 0.01^{b}$ & $0.32 \pm 0.02^{\mathrm{a}}$ \\
\hline Ethylundecanoate $(\mathrm{mg} / \mathrm{L})$ & $2.15 \pm 0.02^{c}$ & $2.10 \pm 0.02^{c}$ & $1.95 \pm 0.02^{b}$ & $1.15 \pm 0.02^{\mathrm{a}}$ \\
\hline 3-Methylbutyl dodecanoate $(\mathrm{mg} / \mathrm{L})$ & $0.34 \pm 0.02^{\mathrm{a}}$ & $0.33 \pm 0.03^{\mathrm{a}}$ & $0.33 \pm 0.02^{\mathrm{a}}$ & $0.26 \pm 0.02^{\mathrm{a}}$ \\
\hline Ethyl dodecanoate $(\mathrm{mg} / \mathrm{L})$ & $1.87 \pm 0.01^{\mathrm{d}}$ & $1.62 \pm 0.02^{\mathrm{c}}$ & $1.25 \pm 0.02^{b}$ & $1.11 \pm 0.02^{\mathrm{a}}$ \\
\hline 3-Methylphenyl butanoate $(\mathrm{mg} / \mathrm{L})$ & $0.28 \pm 0.02^{\mathrm{a}}$ & $0.23 \pm 0.03^{\mathrm{a}}$ & $0.22 \pm 0.02^{\mathrm{a}}$ & $0.20 \pm 0.02^{\mathrm{a}}$ \\
\hline Undecanoic acid (mg/L) & $2.96 \pm 0.02^{c}$ & $2.83 \pm 0.02^{\mathrm{a}}$ & $2.93 \pm 0.02^{\mathrm{b}, \mathrm{c}}$ & $2.88 \pm 0.02^{\mathrm{a}, \mathrm{b}}$ \\
\hline Dodecanoic acid (mg/L) & $0.29 \pm 0.02^{b}$ & $0.26 \pm 0.02^{b}$ & $0.23 \pm 0.02^{b}$ & $0.19 \pm 0.01^{\mathrm{a}}$ \\
\hline Dihydroxyacetone (mg/L) & $2.22 \pm 0.01^{b}$ & n.d. & $2.50 \pm 0.01^{c}$ & $1.20 \pm 0.01^{\mathrm{a}}$ \\
\hline $\begin{array}{l}\text { Dihydro-4-hydroxy-2(3H)- } \\
\text { furanone (mg/L) }\end{array}$ & $0.51 \pm 0.02^{\mathrm{a}}$ & n.d. & $0.52 \pm 0.03^{\mathrm{a}}$ & n.d. \\
\hline
\end{tabular}

n.d. - not detected; tr. - traces; values in the same row with different superscripts $(a-d)$ are significantly different $(P<0.05)$ 
Total extract and total acidity decreased due to immobilized cell technology application, which is consistent with the increase of ethanol content, indicating higher extent of fermentation (Miličević et al., 2014).

Aroma profile of fig distillates is also given in Table 1. According to Trad et al. (2012), the most important classes of fig aroma compounds are esters, ketones and alcohols, with acetoin, butyl acetate, isoamyl acetate and hexyl acetate being the major compounds in mature fruit. The content of isoamyl acetate decreased with application of immobilised cells from $9.60 \mathrm{mg} / \mathrm{L}$ and $9.40 \mathrm{mg} / \mathrm{L}$ to $9.02 \mathrm{mg} / \mathrm{L}$ and $8.35 \mathrm{mg} / \mathrm{L}$ for Petrovača bijela and Petrovača crna, respectively, indicating that immobilization could result in decreased characteristic "fig flavour" of distillates. However, limonene content, which is also an aroma compound of fresh figs, significantly increased due to cell immobilization, probably due to secondary aroma formation reactions during fermentation (Miličević et al., 2012).

Generally, ester contents decreased due to immobilized cell application, indicating that distillates produced by classical fermentation could have a richer aroma. This, however, was not confirmed by sensory analysis, where samples produced by immobilized cells got higher points for odour than samples produced by classical procedure, with close score for taste (Table 2).

Table 2. Sensory analyses of fig distillates - German DLG model (Koch, 1986.)

Tablica 2. Senzorska analiza destilata smokve - Njemački DLG model (Koch, 1986.)

\begin{tabular}{|l|c|c|c|c|}
\hline \multirow{2}{*}{$\begin{array}{l}\text { Sample } \\
\text { Uzorak }\end{array}$} & \multicolumn{3}{|c|}{ Assessment characteristics / Ocjenjivani parameter } \\
\cline { 2 - 5 } & $\begin{array}{c}\text { Clearness } \\
\text { (max 15 points) } \\
\text { Bistroća } \\
\text { (max 15 bodova) }\end{array}$ & $\begin{array}{c}\text { Odour (max 25 points) } \\
\text { Miris (max 25 bodova) }\end{array}$ & $\begin{array}{c}\text { Taste (max 45 points) } \\
\text { Okus (max 45 bodova) }\end{array}$ & $\begin{array}{c}\text { Total } \\
\text { (max 100 points) } \\
\text { (max 100 bodova) }\end{array}$ \\
\hline Petrovača bijela & 15.00 & 15.00 & 22.50 & 45.00 \\
\hline Petrovača crna & 15.00 & 14.90 & 23.50 & 44.10 \\
\hline Petrovača bijela* & 15.00 & 15.00 & 25.00 & 44.10 \\
\hline Petrovača crna* & 15.00 & 15.00 & 24.00 & 97.50 \\
\hline
\end{tabular}

fermented with immobilized yeast cells

Overall sensory quality was higher for samples produced by immobilized cells, indicating that this technique is suitable for production of high-quality fig distillates. In our previous research on tangerine distillates (Miličević et al., 2012), samples produced by immobilized technology had somewhat lower sensory quality than samples produced by using the classical procedure. This implies that, regarding sensory quality, suitability of immobilized cell technology for fermentation in production of distillates depends on the raw material used.

\section{CONCLUSION}

The results of this research indicate that fermentation with immobilized yeast cells results in increased ethanol content, and decreased content of methanol and esters. Sensory quality of fig distillates is improved by immobilized technology application, compared to distillates produced in a classical manner. Therefore, immobilized yeast technology is a promising tool for production of high-quality fruit distillates.

\section{REFERENCES}

1. Apostolopoulou, A.A., Flouros, A.I., Demertzis, P.G., Akrida-Demertzi K. (2005): Differences in concentration of principal volatile constituents in traditional Greek distillates. Food Control, 16: 157-164.

doi: http://dx.doi.org/10.1016/j.foodcont.2004.01.005
2. Diéguez, S.C., de la Peña, M.L.G., and Gómez, E.F., 2005. Volatile composition and sensory characters of commercial Galician Orujo Spirits. J. Agric. Food Chem. 53, 6759-6765. DOI: 10.1021/jf040467j

3. EEC, Council Regulation $2870 / 00$ laying down Community reference methods for the analysis of spirit drinks, Off. J. Eur. Comm. L333 (2000).

4. EEC, Council Regulation 110/2008 on the definition, description and presentation of spirit drinks, Off. J. Eur. Commun. L39 (2008).

5. Fundira, M., Blom, M., Pretorius, I.S., van Rensburg, P. (2002): Selection of yeast starter culture strains for the production of marula fruit wines and distillate. J. Agric. Food Chem., 50: 1535-1542.

doi: http://dx.doi.org/10.1021/jf0111514

6. Gaserod, 0. (1998): Microcapsules of alginate chitosan: A study of capsule formation and functional properties, PhD thesis, NTNU Trondheim.

7. Guan, S.H., Pieper, H.J. (1998): Examination of the distillation characteristics of the distillate from numerous fruit mashes using GC analysis. Deut. Lebensm. Rundsch., 11: 365-374.

8. Kourkoutas, Y., Bekatorou, A., Banat, I. M., Marchant, R., Koutinas, A.A. (2004): Immobilization technologies and support materials suitable in alcohol beverages production: a review. Food Microbiol., 21: 377-397.

doi: http://dx.doi.org/10.1016/j.fm.2003.10.005 
9. Lilly, M., Lambrechts, M.G., Pretorius, I.S. (2000): Effect of increased yeast alcohol acetyltransferase activity on flavor profiles of wine and distillates. Appl. Environ. Microbiol., 2: 744-753.

doi: http://dx.doi.org/10.1128/AEM.66.2.744-753.2000

10. List of Varieties of the Republic of Croatia, 2015. Croatian Centre for Agriculture, Food and Rural Affairs.

11. Lukić, I., Tomas, S., Miličević, B., Radeka, S., Peršurić, Đ. (2011): Behaviour of volatile compounds during traditional alembic distillation of fermented Muscat Blanc and Muškat ruža porečki grape marcs. J. Inst. Brew., 117: 440-450.

doi: http://dx.doi.org/10.1002/j.2050-0416.2011. tb00491.x

12. Miličević, B., Lukić, I., Babić, J., Šubarić, D., Miličević, R., Ačkar, Đ. (2012): The influence of fermentation process with immobilized yeast cells on quality of tangerine distillates. Glasnik zaštite bilja, 5: 68-75.

13. Miličević, B., Babić, J., Šubarić, D., Ačkar, Đ., Jozinović, A., Miličević, R., Klarić, I. (2014): The effects of the fermentation with immobilized yeast and different cherry varieties on the quality of cherry brandy. Croat. J. Food Sci. Technol., 6(2): 104-109

14. Nykanen, L., Suomalainen, H. (1983): Aroma of beer, wine and distilled alcoholic beverages, Akademie verlag, Berlin.

15. Paine, A.J., Dayan, A.D. (2001): Defining a tolerable concentration of methanol in alcoholic drinks. Hum. Exp. Toxicol., 20: 563-568.

doi: http://dx.doi.org/10.1191/096032701718620864

16. Plutowska, B., Biernacka, P., Wardencki, W. (2010): Identification of volatile compounds in raw spirits of different organoleptic quality. J. Inst. Brew., 116: 433439.

doi: http://dx.doi.org/10.1002/j.2050-0416.2010. tb00794.x

17. Plutowska, B., Wardencki, W. (2009): Headspace solid-phase microextraction and gas chromatography-olfactometry analysis of raw spirits of different organoleptic quality. Flavour Frag. J., 24: 177-185.

doi: http://dx.doi.org/10.1002/ffj.1930
18. Pohanka, M. (2016): Toxicology and the biological role of methanol and ethanol: Current view, Biomed. Pap., 160: 54-63.

doi: http://dx.doi.org/10.5507/bp.2015.023

19. Poncelet, D., Dulieu, C., Jacquot, M. (2001): Description of the immobilization procedures, In: Immobilized Cells, (Wijffels R.), Springer Lab Manual, Heidelberg, pp. 15-30.

20. Rotim, N. (2008): Rakija od smokve (Fig brandy). In: Smokva (Fig). (Vego, D., Ostojić, I., Rotim, N). Mostar University, Mostar, B\&H, 2008.

21. Singleton, V.L. (1995): Maturation of wines and spirits comparisons, facts, and hypoteses. Am. J. Enol. Vitic., 1: $98-112$.

22. Soufleros, E.H., Mygdalia, S.A., Natskoulis, P. (2005): Production process and characterization of the traditional Greek fruit distillate "Koumaro" by aromatic and mineral composition. J. Food Comp. Anal., 18: 699-716. doi: http://dx.doi.org/10.1016/j.jfca.2004.06.010

23. Trad, M., Ginies, C., Gaaliche, B., Renard, C.M.G.C., Mars, M. (2012): Does pollination affect aroma development in ripened fig (Ficus carica L.) fruit? Sci. Hortic., 134: 93-99.

doi: http://dx.doi.org/10.1016/j.scienta.2011.11.004

24. Vila, I., Sablayrolles, J.M., Baumes, R., Bayonove, C., Barre, P. (1998): Study of influence of yeast strain on fermentation aroma by sensory and chemical analyses. Vitic. Enol., 53: 124-130.

25. Virkajarvi, I., Kronolof, J. (1998): Long-term stability of imobilized yeast columns in primary fermentation. J. Am. Soc. Brew. Chem., 56: 70-75. doi: http://dx.doi.org/10.1094/ASBCJ-56-0070

26. Willemsens, C., Boelsens, M.H. (eds) (1996): Volatile compounds in food: qualitative and quantitative data. 7th ed. TNO Nutrition and Food Research Institute, Zeist.

27. Williams, P.J., Piggot, J.R. (1983): The effect of distillation on grape flavour, Ellis Horwood Limited, Chichester.

28. Yajima, M., Yokotsuka, K. (2001): Volatile compound formation in white wines fermented using immobilized and free yeast. Am. J. Enol. Vitic., 52: 210-218. 


\section{UTJECAJ FERMENTACIJE S IMOBILIZIRANIM STANICAMA KVASCA NA PROFIL AROME I SENZORSKU KVALITETU RAKIJA PROIZVEDENIH IZ DVIJU SORTI SMOKVE (Ficus carica L.)}

\section{SAŽETAK}

Cilj ovoga rada bio je ispitati utjecaj fermentacije pomoću imobiliziranih stanica kvasca na aromu i senzorska svojstva destilata proizvedenih od dviju sorti smokve koje se uzgajaju u Republici Hrvatskoj (Petrovača bijela i Petrovača crna). Uzorci destilata proizvedeni su klasičnim postupkom i pomoću imobiliziranih stanica kvasca. Profil arome određen je pomoću GC/FID-a, a senzorska analiza provedena je prema njemačkome DLG modelu. Rezultati su pokazali da postupak s imobiliziranim stanicama kvasca daje destilate $s$ višim udjelom etanola i nižim udjelima estera, ali bolje senzorske kvalitete. Taj postupak ima velik potencijal u proizvodnji visokokvalitetnih voćnih destilata.

Ključne riječi: imobilizirane stanice kvasca, smokva, destilat, aroma, senzorska svojstva

(Received on 1 September 2016; accepted on 4 May 2017 - Primljeno 01. rujna 2016.; prihvaćeno 04. svibnja 2017.) 